\title{
Validation of Integrated Crop Management (ICM) Practices over Farmers' Practices in Mungbean
}

\author{
Ganajaxi Math*, Gurupada Balol, T.M. Ashwini and Lalitha Jaggal \\ AICRP on MULLaRP, University of Agricultural Sciences, Dharwad-580 005, \\ Karnataka, India \\ *Corresponding author
}

\begin{tabular}{|l|}
\hline Ke y w o r d s \\
Integrated Crop \\
Management (ICM), \\
Farmers' practices, \\
Mungbean
\end{tabular}

\section{Introduction}

In India mungbean is grown in an area of 4.32 $\mathrm{m}$ ha with a total production of $2.17 \mathrm{~m} \mathrm{t}$ and average productivity of $502 \mathrm{~kg}$ per hectare. In Karnataka it occupies an area of 4.23 lakh ha with a production of 1.17 lakh tonnes and an average productivity of only $277 \mathrm{~kg} / \mathrm{ha}$.

Integrated Crop Management (ICM) is a pragmatic approach to the production of crops, which combine a range of complementary methods to reduce a pest population below its
The experiment was conducted at Main Agricultural Research Station (MARS), University of Agricultural Sciences, Dharwad during the rainy season of 2015 under rainfed condition to validate the integrated crop management practices with farmers' practice. DGGV-2 variety was used for the experiment. Treatments consisted of two dates of sowing [Normal sowing date of the location (June $16^{\text {th }}$ ) and 15 days after normal sowing date] and two types of practices i.e. ICM v/s farmers' practice [Improved nutrient, weed and pest and disease management practices $\mathrm{v} / \mathrm{s}$ farmers' practice] and they were sown in four blocks of $100 \mathrm{~m}^{2}$. There was 30.6 per cent decrease in yield in ICM practice is due to delay of wowing by 15 days, where in farmer's practice it was 41.3 per cent under normal sowing due to farmer's practice yield was reduced by 24.7 per cent $(855 \mathrm{~kg} / \mathrm{ha})$ compared to ICM practice $(1066 \mathrm{~kg} / \mathrm{ha})$. The yield reduction in farmers practice under delayed sowing was 76.8 per cent compared to ICM under normal sowing. Maximum net returns were obtained in normal sown ICM (50120 Rs/ha) when compared to normal sown farmer's practice (36350 RS/ha), 15 days late sown ICM (32620 Rs/ha) and 15 days late sown crop with farmers practice $(18710 \mathrm{Rs} / \mathrm{ha})$ The overall analysis of the study revealed that adoption of ICM technologies in greengram cultivation results in high profits. 


\section{Materials and Methods}

The experiment was conducted at Main Agricultural Research Station (MARS), University of Agricultural Sciences, Dharwad during the rainy season of 2015 under rainfed condition to validate the improved crop production techniques with farmers' practice.

The geographical co-ordinates of Dharwad are $15^{\circ} 26^{\prime} \mathrm{N}$ latitude and $75^{\circ} 7^{\prime} \mathrm{E}$ longitude and an altitude of $678 \mathrm{~m}$ above mean sea level. It is located in the Northern Transition Zone of Karnataka which has semi-arid climate.

The soil of the experimental site was clayey in nature and having available N, P and $\mathrm{K}$ of 210 , 19.5 and $342.8 \mathrm{~kg} / \mathrm{ha}$, respectively. Organic carbon (\%) and $\mathrm{pH}$ of the soil were, respectively, $0.52 \%$ and 7.2.DGGV 2 variety was used for the experiment.

Treatments consisted of two dates [Normal sowing date of the location (June $16^{\text {th) }}$ and 15 days after normal sowing date] two types of practices [Integrated crop management includes nutrient management (5t FYM/ha with 25:50 kg N: $\mathrm{P}_{2} \mathrm{O}_{5}$ and Rhizobium and PSB inoculation at the time of sowing and 2\% DAP spray at flowering and pod initiation stages), weed management (pre-emergent application of pendimethalin 33\% EC @ 1 kg/ha followed by one hand weeding at 25 DAS for the control of major weeds i.e. Commelina bengalensis, Digitaria marginata, Alternethra sessail, Acarynthus aspera, Euphorbia hirta, Echinoclova crussgalli and Amaranthus viridis) disease management (Leaf spots and powdery mildew were controlled by spraying hexaconazole @ $1 \mathrm{ml}$ per litre [Fig. 1 (a)] and pest management (with insecticides such as monocrotophos@1.5 ml per litre for the control of aphids and whiteflies, imidacloprid @ $1 \mathrm{ml}$ per litre of water for the control of spingid moth and bihar hairy catterpiller and Lambda cylothrin@0.5 ml per litre of water for the control of apion beetle [Fig.1 (b)] and farmers' practice $(100 \mathrm{~kg} \mathrm{DAP} / \mathrm{ha}$, two intercultivations at 15 and $30 \mathrm{DAS}$ fb one hand weeding at 20 DAS, monocrotophos @ $1.5 \mathrm{ml}$ per litre for control of sucking pests and hexaconazole @ $1 \mathrm{ml}$ per litre for control of leaf spots and powdery mildew). Treatments were sown in four blocks of 100 $\mathrm{m}^{2}$ [Fig 2(a) and (b)].

\section{Results and Discussion}

There was 30.6 per cent decrease in yield in ICM practice due to delay of sowing by 15 days, where in farmer's practice it was 41.3 per cent.

Under normal sowing due to farmer's practice yield was reduced by 24.7 per cent $(855 \mathrm{~kg} / \mathrm{ha})$ compared to ICM practice (1066 kg/ha).

The yield reduction in farmers practice under delayed sowing was 76.8 per cent compared to ICM under normal sowing (Table 1. and Fig. $3)$.

These results were similar with the findings of Reddy et al., 2011; Salla Sowjanya et al., 2017 in chilli crop and Wang et al., 2017 in rice crop.

Maximum net returns were obtained in normal sown ICM (50120 Rs/ha) when compared to normal sown farmer's practice (36350 RS/ha), 15 days late sown ICM (32620 Rs/ha) and 15 days late sown crop with farmers practice (18710 Rs/ha) (Fig. 4).

Major pests in late sown crop with farmers' practice were sphingid moth, aphids, whiteflies, bihar hairy catterpiller and apion beetle and the percent disease incidence (PDI) of the powdery mildew, cercospora leaf spot and anthrachnose leaf spot were 35 to $45 \%$ higher in 15 days late sown crop with farmers, practice when compared to normal sown ICM. 
Table.1 Yield, yield parameters and economics as influenced by ICM and farmer's practice under normal and late sowing in greengram

\begin{tabular}{|l|}
\multicolumn{1}{|c|}{ Parameters } \\
\hline Plant ht(cm) \\
\hline Branches \\
\hline Pods/plants \\
\hline Dry wt (g) \\
\hline 100 Seed wt(g) \\
\hline Yield (kg/ha) \\
\hline Gross return Rs/ha \\
\hline Cost of cultivation Rs/ha \\
\hline Net return Rs/ha \\
\hline
\end{tabular}

\begin{tabular}{|c|c|c|c|c|}
\hline \multicolumn{2}{|c|}{ Normal sowing } & \multicolumn{2}{|c|}{ 15 days late sowing } \\
\hline ICM & Farmers practice & ICM & Farmers practice \\
\hline 50.00 & 49.00 & 46.00 & 46.33 \\
\hline 2.66 & 2.33 & 2.33 & 1.66 \\
\hline 11.66 & 10.00 & 8.00 & 6.66 \\
\hline 12.30 & 11.30 & 9.00 & 7.90 \\
\hline 4.74 & 3.955 & 3.05 & 2.64 \\
\hline 1066 & 855 & 816 & 603 \\
\hline 74620 & 59850 & 57120 & 42210 \\
\hline 24500 & 23500 & 24500 & 23500 \\
\hline 50120 & 36350 & 32620 & 18710 \\
\hline
\end{tabular}

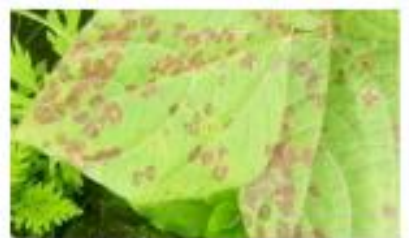

Anthracnose

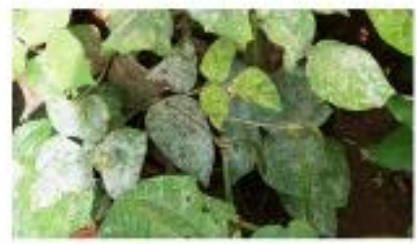

Powdery mildew

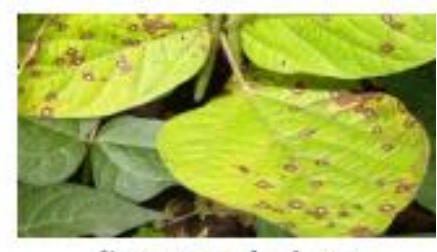

Cercospora leal' spot

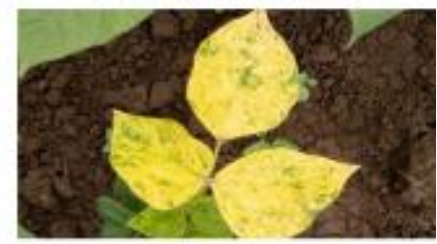

Yellow mosaic

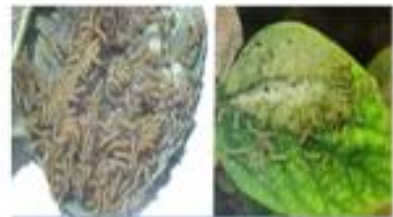

Bihar hairy caterpillar

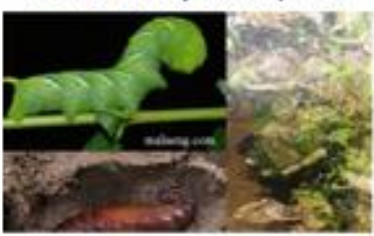

Spingid moth

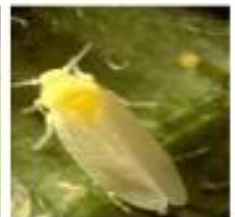

Whitefly

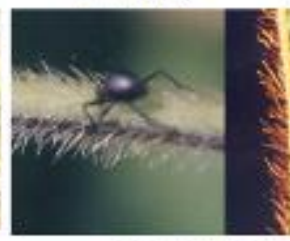

Apion beetle

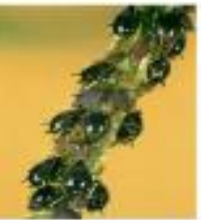

Aphid

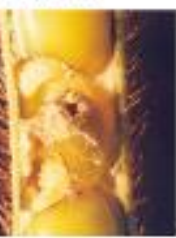

Fig.1 (a) Important diseases observed in the experiment (b) Important pests observed in the experiment

Fig.2 (a) Field view of the experiment under normal sowing

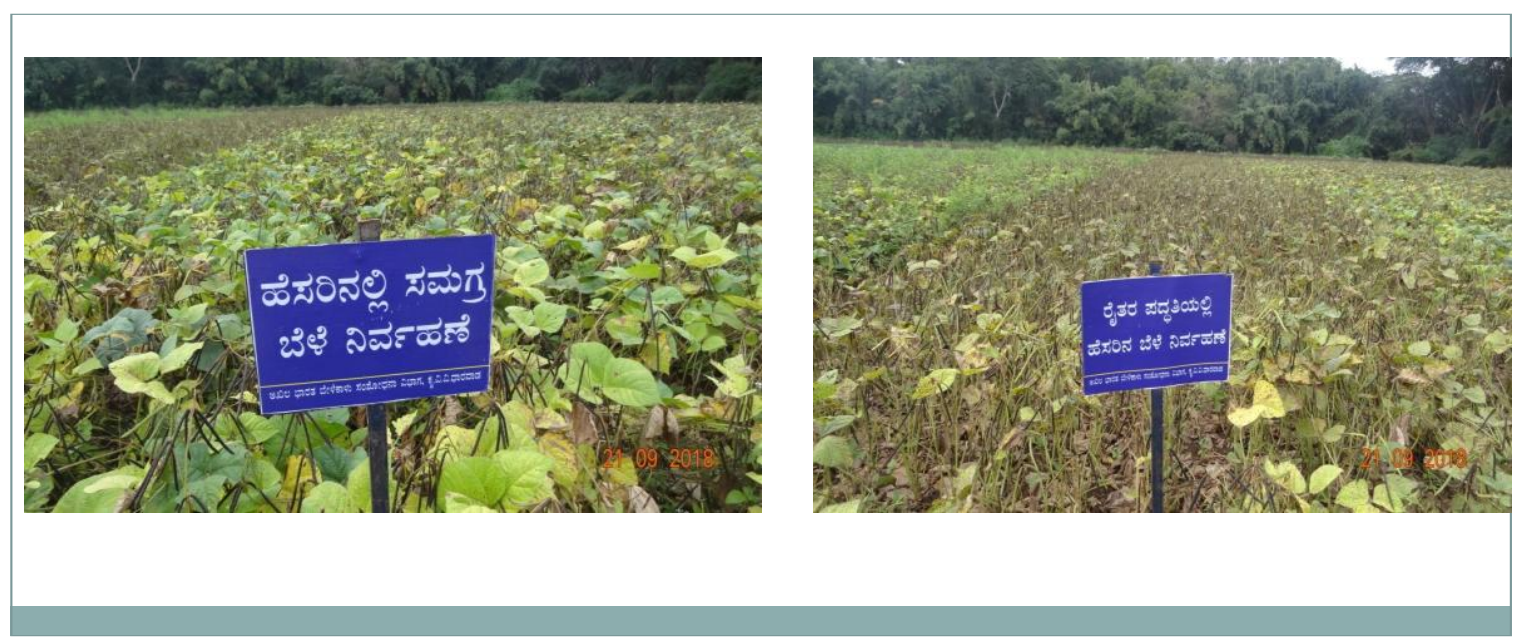


Fig.2 (b) Field view of the experiment under 15 days delayed sowing

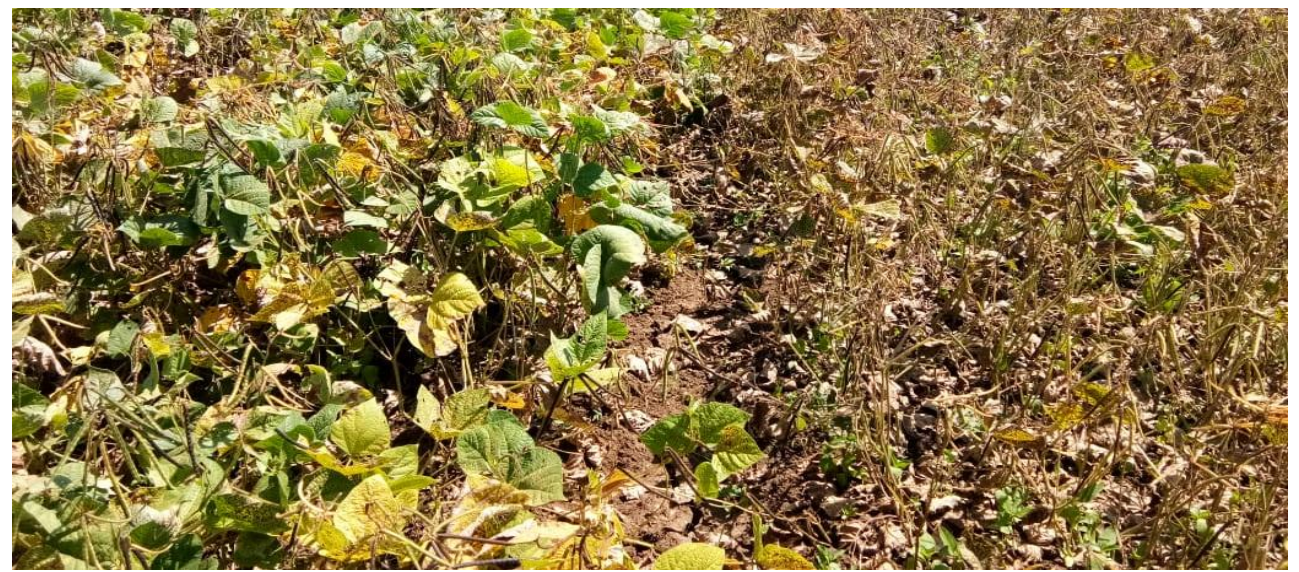

\section{Mungbean with ICM practice Mungbean with farmer's practice}

Fig.3 Yield and yield parameters as influenced by ICM and farmer's practice under normal and late sowing in greengram

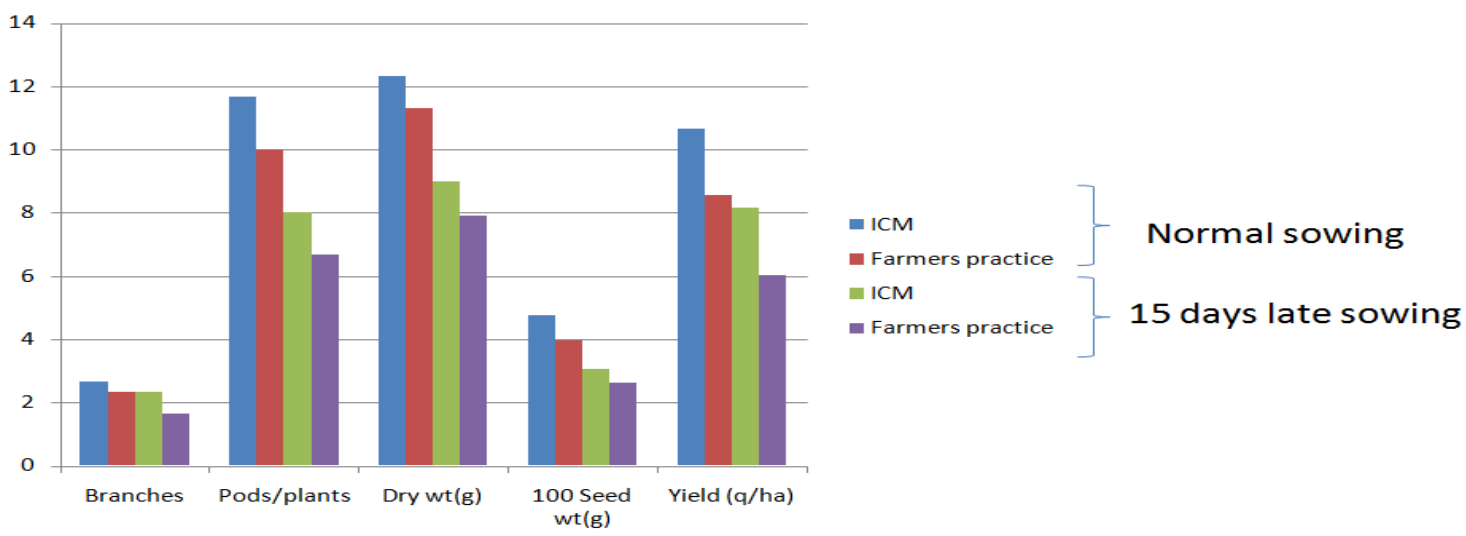

Fig.4 Yield and Economics of greengram as influenced by normal and late sowing

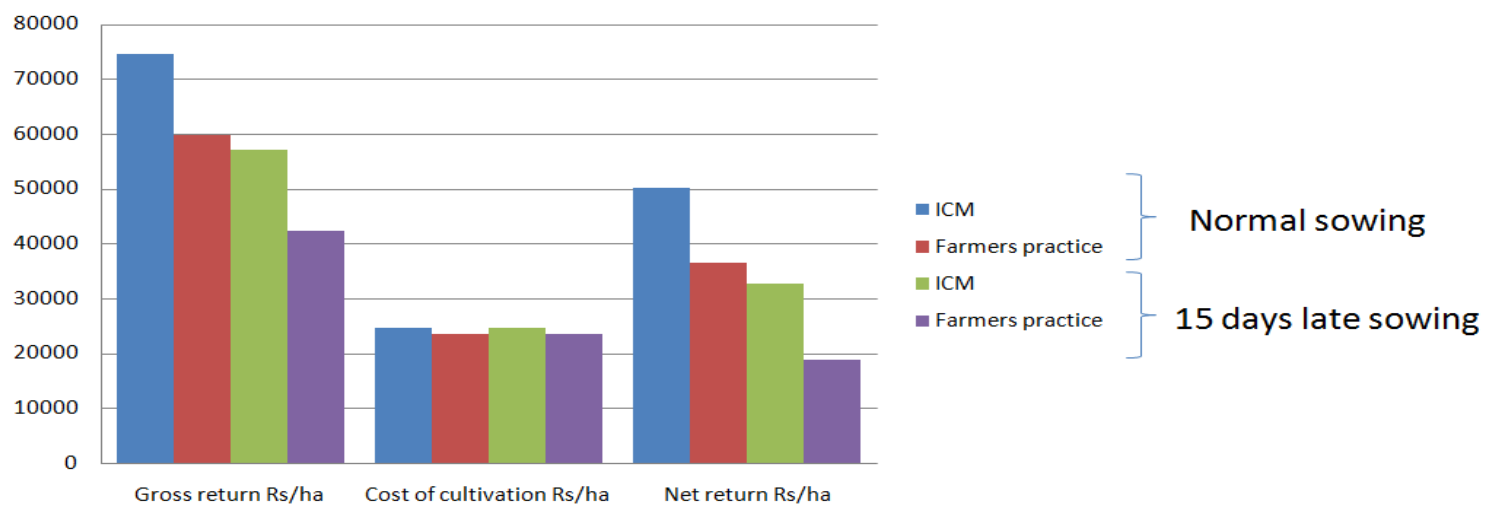


Present study indicated that ICM is definitely better over farmer's practices under different weed, pest and disease infestation. ICM implies the rational integration of various methods of weed, insect, pest and disease control to suppress them below ETL. Therefore, farmers should be made aware of its benefits and motivated to critically analyze and make decisions regarding ICM practices.

\section{References}

Kogan, M, 1998. Integrated Pest Management: historical perspectives and contemporary developments. Annual Review of Entomology, 43: 243-270.
Reddy, C.M., Reddy, G.K., Tirupamma, K and Reddy, S.K.V. 2011. Economics of integrated pest management (IPM) in chilli in Guntur district of Andhra Pradesh. International Journal of Plant, Animal, Environmental Sciences. 1(1):140-143.

Salla Sowjanya, R., Vijaya Kumari, V.V., Deekshitulu, R., and Suresh, J., 2017, Comparative Effect of Integrated Crop Management and Farmers' Standard Practice in Chilli Crop, Int.J.Curr.Microbiol.App.Sci., $\quad 6(8)$ : 2332-2337

Wang D, Huang J, Peng. S., 2017, Integrated crop management practices for maximizing grain yield of double season rice crop. Sci. Rep. 7: 38982.

\section{How to cite this article:}

Ganajaxi Math, Gurupada Balol, T.M. Ashwini and Lalitha Jaggal. 2018. Validation of Integrated Crop Management (ICM) Practices over Farmers' Practices in Mungbean. Int.J.Curr.Microbiol.App.Sci. 7(11): 547-551. doi: https://doi.org/10.20546/ijcmas.2018.711.065 